\title{
The religious body imagined
}

\author{
Pamela D. Winfield
}

Well-established approaches to the study of religion tend to neglect the fundamental role that individual human actors, with very human bodies, play in both constructing and reinforcing what we call 'religion' in our world. That is, they often overlook the fact that that our own embodied experience shapes our conceptions of the sacred (however that may be defined) and, conversely, that our bodies also express, re-instantiate, and re-embody those invisible contours of our socially constructed sacred idea(l)s in concrete physical forms. As a result, this multireligious and interdisciplinary volume of global scope seeks to provide both historic and contemporary perspectives on the human experience of human embodiment specifically as it pertains to religious thought and practice on the ground.

This issue of Body and Religion offers fascinating glimpses into how the religious body has been imagined and cultivated, as well as problematized and negotiated, through visual, literary, and lived realities. It brings together five essays that were first accepted for presentation at an international symposium on The Religious Body Imagined that was hosted by Elon University's Center for the Study of Religion, Culture and Society (CSRCS) in February, 2019. This conference set out to 'examine the ways in which the religious body has been imagined, imaged, and discursively produced in particular places, times, and religious traditions.' As a result, this journal issue contributes new and original research as well as theoretical insights that can substantially help to expand our understanding of the interdisciplinary field of religion and body studies in general.

\footnotetext{
$\overline{\text { Affiliation }}$

Elon University, North Carolina, USA. email:pwinfield@elon.edu
} 
Michal Raucher's 'People of the book, women of the body: ultra-orthodox Jewish women's reproductive literacy' relies on two years of ethnographic research among Haredi mothers in Jerusalem. Her research reveals that the women's lived experience of repeated pregnancies cultivates a kind of embodied knowledge and self-reliant, self-validating authority that no longer consults the normative rabbinic and male-dominated authority systems that regulate all other sectors of Haredi life. In so doing, Raucher expands our understanding of embodied female agency in a tradition that has long been assumed to subjugate women.

In contrast to Raucher's explicit focus on the female-identified body, Elizabeth Rhodes investigates a handful of understudied texts related to 'The male body and Catholic piety in early modern Spain.' She observes that monks in monasteries also imagined themselves as conjugal brides of Christ and engaged in many of the same devotional practices as the better studied nuns in Spanish and Hispanic convents. Because these men practiced 'ardent devotion to the Eucharist, strict food management and manipulation, as well as extreme asceticism justified by pious intentions, (131) just like the nuns did, Rhodes calls into question the presumed gendered nature of early modern Catholic piety.

Mina Garcia also looks at the religious body in Counter-Reformation Spain in 'Lope's Hamete de Toledo: the infidel's body as conquered land.' In this baroque tragedy with religio-political overtones, the celebrated playwright Lope de Vega (1562-1635) expresses the then-current anti-Muslim sentiments of King Philip II's Morisco Expulsion Decree of 1609 and dramatizes the auto-da-fé of a sympathetic yet enslaved Muslim nobleman who ultimately converts to Christianity upon physical torture and pain of death. A recent re-staging of Lope's play by AlmaViva Teatro (Living Soul Theater) highlights the inhuman injustice of Othering, especially in the islamophobic context of contemporary Euro-American immigration policies and President Trump's Muslim ban.

Saqer A. Almarri takes up and brings together the above-mentioned themes of gender and Islam in their illuminating study of 'Non-binary sexual and gender identities in the community: the khuntha as an isolated being in the mosque.' In this analysis, Almarri provides a historically, historiographically, and theoretically rich study of a fourteenth-century legal manual by the Shāfi'i jurist al-Isnawī (d. 772 AH 1370 CE), who details the exact legal and therefore logistical standing of an intersex person within the segregated prayer space of the Mamlūk mosque. The manual acknowledges and attempts to accommodate the khunthā within the mosque's strictly binary social space, but Almarri argues that dedicating a prayer row between the cisgendered men and women, and ordering each khunthā to 
exit the mosque one by one after the women and before the men, actually 'outs' them before the congregation and socially isolates them instead of integrating them into the community of worshippers.

Finally, Anandi Knuppel likewise looks at the lived experiences of practitioners in the ritual setting, but she shifts our focus to contemporary Hindu devotional expression. 'Seeing, imagined and lived: creating darshan in transnational Gaudiya Vaishnavism' presents the traditional rules and protocols for taking darśan (to see and be seen by the deity), but then also presents contemporary firsthand accounts that expand and redefine darśan beyond the merely visual dimension to include multisensory embodied performance of dancing, singing, eating, listening, chanting and dressing the image. Relying on eight years of ethnographic work among the International Society of Krishna Consciousness (ISKON) community in the southeastern United States, Knuppel's essay reveals that these multisensory 'darshanic moments' help 'to purify the devotee from their "material conditions" so that they can proceed to further their devotion and love' (191).

In this way, Knuppel's contemporary study of Hindu bhakti provides a fitting bookend to Raucher's ethnographic analysis of ultra-Orthodox Jewish women, while Rhodes, Garcia and Almarri inbetween provide more historic studies of border crossing Catholic and Muslim embodiments. By exploring how the religious body has been imagined through a range of disciplinary and theoretical lenses (e.g. visual culture, literary, performance and cultural studies, ethnography, space/place, ritual, postcolonial theory and social justice as it pertains to embodiment), this journal issue explores the religious body's various functions, roles, and transformative effects in some of the world's most vibrant traditions and geo-historical locations. 